\title{
Structure of the central Sumatran subduction zone revealed by local earthquake travel-time tomography using an amphibious network
}

\author{
Dietrich Lange $^{1}$, Frederik Tilmann ${ }^{2,6}$, Tim Henstock ${ }^{3}$, Andreas Rietbrock ${ }^{4}$, Danny Natawidjaja ${ }^{5}$, and \\ Heidrun Kopp ${ }^{1,7}$ \\ ${ }^{1}$ Dynamics of the Ocean Floor, GEOMAR, Helmholtz Centre for Ocean Research Kiel, Kiel, Germany \\ ${ }^{2}$ Helmholtz-Zentrum Potsdam, Deutsches GeoForschungsZentrum GFZ, Potsdam, Germany \\ ${ }^{3}$ Ocean and Earth Science, University of Southampton European Way, Southampton, SO14 3ZH, UK \\ ${ }^{4}$ Karlsruhe Institute of Technology, Geophysical Institute, Karlsruhe, Germany \\ ${ }^{5} \mathrm{RC}$ Geotechnology, Indonesian Institute of Sciences (LIPI), Bandung, Indonesia \\ ${ }^{6}$ Institute of Geological Sciences, Freie Universität Berlin, Berlin, Germany \\ ${ }^{7}$ Department of Geosciences, Christian-Albrechts-Universität zu Kiel, Kiel, Germany
}

Correspondence: Dietrich Lange (dlange@geomar.de)

Received: 23 November 2017 - Discussion started: 4 January 2018

Revised: 7 March 2018 - Accepted: 31 July 2018 - Published: 21 August 2018

\begin{abstract}
The Sumatran subduction zone exhibits strong seismic and tsunamogenic potential with the prominent examples of the 2004, 2005 and 2007 earthquakes. Here, we invert travel-time data of local earthquakes for $v_{\mathrm{p}}$ and $v_{\mathrm{p}} / v_{\mathrm{s}}$ velocity models of the central Sumatran forearc. Data were acquired by an amphibious seismometer network consisting of 52 land stations and 10 ocean-bottom seismometers located on a segment of the Sumatran subduction zone that had not ruptured in a great earthquake since 1797 but witnessed recent ruptures to the north in 2005 (Nias earthquake, $M_{\mathrm{w}}=8.7$ ) and to the south in 2007 (Bengkulu earthquake, $M_{\mathrm{W}}=8.5$ ). The 2-D and 3-D $v_{\mathrm{p}}$ velocity anomalies reveal the downgoing slab and the sedimentary basins. Although the seismicity pattern in the study area appears to be strongly influenced by the obliquely subducting Investigator Fracture Zone to at least $200 \mathrm{~km}$ depth, the 3-D velocity model shows prevailing trench-parallel structures at depths of the plate interface. The tomographic model suggests a thinned crust below the basin east of the forearc islands (Nias, Pulau Batu, Siberut) at $\sim 180 \mathrm{~km}$ distance to the trench. $v_{\mathrm{p}}$ velocities beneath the magmatic arc and the Sumatran fault zone (SFZ) are around $5 \mathrm{~km} \mathrm{~s}^{-1}$ at $10 \mathrm{~km}$ depth and the $v_{\mathrm{p}} / v_{\mathrm{s}}$ ratios in the uppermost $10 \mathrm{~km}$ are low, indicating the presence of felsic lithologies typical for continental crust. We find moderately elevated $v_{\mathrm{p}} / v_{\mathrm{s}}$ values of 1.85 at $\sim 150 \mathrm{~km}$ distance to
\end{abstract}

the trench in the region of the Mentawai Fault. $v_{\mathrm{p}} / v_{\mathrm{s}}$ ratios suggest an absence of large-scale alteration of the mantle wedge and might explain why the seismogenic plate interface (observed as a locked zone from geodetic data) extends below the continental forearc Moho in Sumatra. Reduced $v_{\mathrm{p}}$ velocities beneath the forearc basin covering the region between the Mentawai Islands and the Sumatra mainland possibly reflect a reduced thickness of the overriding crust.

\section{Introduction}

The largest earthquakes on Earth occur along subduction zones where the oceanic plate is subducted beneath an upper continental plate and large stress is accumulated during the interseismic phase of the seismic cycle. Offshore Sumatra, the oceanic Indo-Australian plate subducts obliquely beneath the Eurasian plate (Fig. 1). In the last decade, the margin hosted a number of great earthquakes on the subduction thrust (Aceh-Andaman, 26 December 2004, $M_{\mathrm{W}}=9.2$; Nias, 28 March 2005, $M_{\mathrm{w}}=8.6$; Bengkulu, 12 September 2007, $M_{\mathrm{w}}=8.5$ ). Additionally, major events such as the intermediate depth $M_{\mathrm{w}}=7.6$ earthquake of 30 September 2009 (e.g., McCloskey et al., 2010; Wiseman et al., 2012) and the 
shallow and slow rupture of the 25 October 2010 Mentawai tsunami earthquake $\left(M_{\mathrm{w}}=7.8\right.$; Bilek et al., 2011 ; Lay et al., 2011; Newman et al., 2011) were associated with significant loss of life. Yet, a part of the margin near the northern Mentawai Islands (below Siberut) remains unbroken since 1797 (Newcomb and McCann, 1987; Natawidjaja et al., 2006; Konica et al., 2008; Chlieh et al., 2008; McCloskey et al., 2010). The region is strongly coupled as inferred from GPS observations and coral data (Chlieh et al., 2008). Further to the south, geodetic records suggest that only half of the interseismic tectonic strain accumulated since the great earthquake of 1833 (Fig. 1) might have been released by the 2007 Bengkulu earthquake (Konca et al., 2008). Sieh et al. (2008) estimate the slip deficit below Siberut Island since the large ruptures of 1797 and 1833 to be $\sim 8 \mathrm{~m}$ and a reduced slip deficit of $\sim 5 \mathrm{~m}$ for the Batu Islands due to the lower degree of coupling in the region of the Batu Islands (Fig. 2 and Chlieh et al., 2008). Therefore, the segment is in an advanced stage of the seismic cycle, although east of Siberut Island there has been significant intra-slab seismic activity, including the $M_{\mathrm{w}}=7.6$ Padang earthquake on 30 September 2009 (Fig. 2) at intermediate depth $(\sim 85 \mathrm{~km})$, which caused significant damage in the city of Padang. Based on Coulomb stress modeling, McCloskey et al. (2010) suggest that the 2009 Padang earthquake did not significantly relax the accumulated stress on the Mentawai segment leaving the threat of a great tsunamogenic earthquake on the Mentawai patch below Siberut Island unabated (e.g., Konca et al., 2008; Sieh et al., 2008).

The down-dip limit of subduction thrust earthquakes was suggested to be a function of temperature at the plate interface and to be controlled by the transition from unstable to stable sliding along the plate interface (e.g., Tichelaar and Ruff, 1993). Hyndman et al. (1997) estimate the maximum temperature for seismic behavior to be $350^{\circ} \mathrm{C}$, while large earthquakes may propagate with decreasing slip down to the $450{ }^{\circ} \mathrm{C}$ isotherm. An additional limiting factor of the seismogenic zone results from the presence of hydrated minerals (serpentinite) in the forearc mantle wedge, suggesting that the down-dip limit of the seismogenic zone correlates to the upper plate Moho (Oleskevich et al., 1999). However, for the Sumatran margin the seismogenic zone is suggested to reach below the continental Moho based on gravity surveys and wide-angle refraction and local earthquake tomography (Siberut: Simoes et al., 2004; Kieckhefer et al., 1980, $\sim 30 \mathrm{~km}$ Moho depth; Aceh basin and Simeulue: Dessa et al., 2009; Klingelhoefer et al., 2010; Tilmann et al., 2010, 21-25 km Moho depth; southern Mentawai Islands: Collings et al., 2012, less than $30 \mathrm{~km}$ Moho depth). For central Sumatra Chlieh et al. (2008) estimate the width of the seismogenic zone based on geodetic data between 20 and $50 \mathrm{~km}$, with the largest width approximately alongside Siberut, and the smallest widths at the Batu Islands and between Sipora and the Pagai islands.

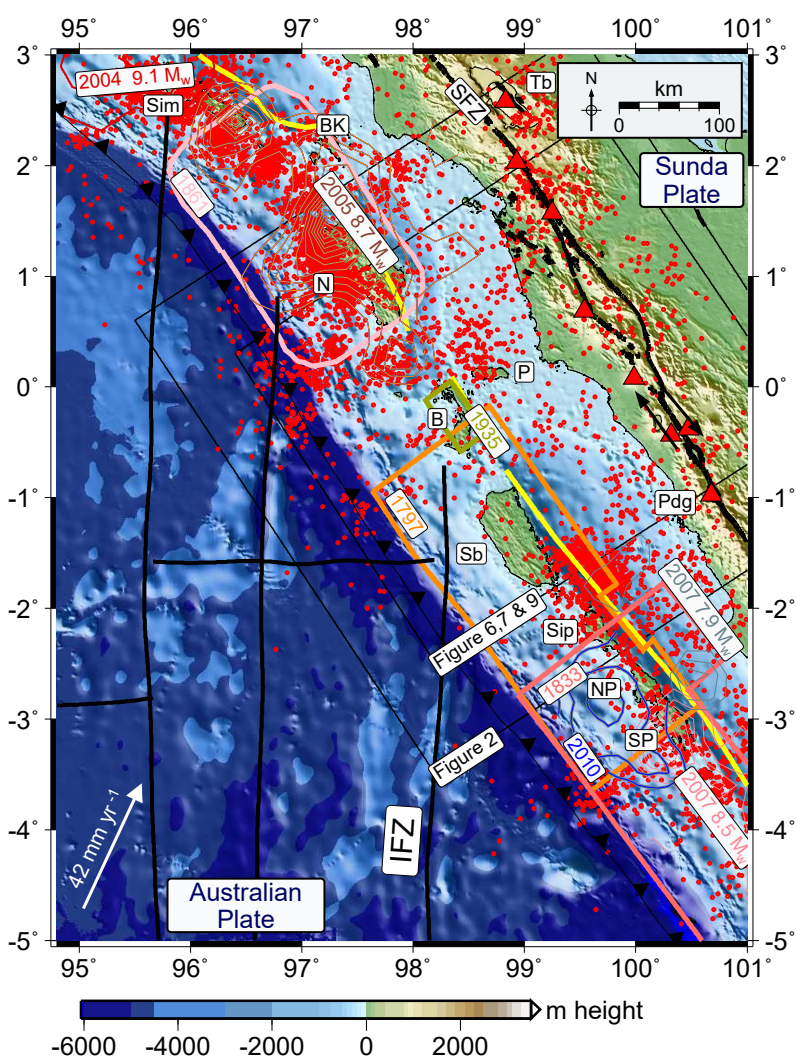

Figure 1. Map showing the tectonic setting of the central Sumatran subduction zone. The locations of earthquakes are indicated by red circles (NEIC catalogue, $M \geq 6,1$ January 1990 until 1 September 2017). The Mentawai Fault (Diament et al., 1992; green line offshore) and the Sumatran Fault (Sieh and Natawidjaja, 2000; black line onshore) are also shown. Bathymetry and topography from the SRTM Plus database (Becker et al., 2009). Oceanic fracture zones from Cande et al. (1989) and Tang et al. (2013). Rupture zones of the great 1797 and 1833 earthquakes are based on uplift of coral microatolls (Natawidjaja et al., 2006). Rupture areas of the 1861, 1935 and 1984 earthquakes are given by Rivera et al. (2002). Slip distribution of the 2004 earthquake from Chlieh et al. (2007). Slip distribution of the 2005 and 2007 earthquakes from Konca et al. (2007, 2008). Convergence between the Australian plate and the forearc sliver from McNeill and Henstock (2014). Volcanoes (Smithsonian Institute) shown with red triangles. Black boxes indicate locations of Figs. 2, 6, 7 and 9. Abbreviations: Sim: Simeulue; BK: Banyak Islands; Tb: Toba; N: Nias; B: Batu Islands; P: Pulau Pini; Sb: Siberut Island; Sip: Sipora; NP: North Pagai; SP: South Pagai; Pdg: Padang.

Previous local earthquake tomography studies were conducted in northern Sumatra focussing on the crustal structure of the region around Lake Toba (Masturyono et al., 2001; Koulakov et al., 2009, 2016; Stankiewicz et al., 2010) or on the shallow crustal structure along the Sumatran Fault (Muksin et al., 2013). Pesicek et al. (2010) imaged the deeper slab geometry including the upper mantle and transition along the Sumatra, Andaman and Burma subduction zones 
using a regional-global body wave tomography. Offshore, the tomography study of Collings et al. (2012) resolves the deeper structure beneath north and south Pagai where the 25 October 2010 tsunamogenic event occurred. Structural information is known from active seismic reflection and refraction studies for a significant number of profiles (e.g., Franke et al., 2008; Dean et al., 2010; Klingelhoefer et al., 2010; Mukti et al., 2012; Shulgin et al., 2013). The Mentawai Fault (Diament et al., 1992), located between the forearc islands and the mainland, was recently imaged as a southwest dipping back-thrust (e.g., Singh et al., 2010; Wiseman et al., 2011). However, there is only limited information about the deep forearc structure and the seismogenic zone (down to depths of $\sim 50 \mathrm{~km}$ ) of the central Sumatran margin.

Offshore central Sumatra, a $\sim 2500 \mathrm{~km}$ long NS trending topographic feature, the Investigator Fracture Zone (IFZ), is situated on the incoming Indo-Australian plate and is subducted at a rate of $57 \mathrm{~mm} \mathrm{yr}^{-1}$ below the Sumatran mainland (Fig. 1). Seismicity occurring in the prolongation of the IFZ down to depths of $200 \mathrm{~km}$ presumably reflects the subducting trace of the IFZ (Fauzi et al., 1996; Lange et al., 2010). At shallower depths, beneath the Batu Islands, both the forearc crust and the plate interface are characterized by enhanced seismicity levels with a number of persistent clusters. This region hosted several major events during the last century (e.g., $1935 M_{\mathrm{w}}=7.7$ and $1984 M_{\mathrm{w}}=7.2$; Rivera et al., 2002) but was not affected by great earthquakes in the last 220 years at least (Konca et al., 2008). Together with the decreased locking this justifies its identification as a persistent segment barrier (Natawidjaja et al., 2006).

The development of the forearc basin between the Sumatran mainland and the island of Nias was described in Matson and Moore (1992). Overall, the Sumatran margin is characterized by rapid accretion since the early Oligocene with current trench fill ages from Quaternary to Eocene ages (Moore et al., 1982). The uplift rates of Nias slope sediments is suggested to be on the order of 100-300 $\mathrm{m}$ my and accreted material has been uplifted by more than $800 \mathrm{~m}$ in the center of Nias island (Moore et al., 1980).

In order to investigate the deep structure of the central Sumatran subduction zone, a dense, temporary and amphibious (on-offshore) seismic network was installed in central Sumatra in 2008. Besides local seismicity, the main target of the seismometer network was to obtain velocity models of the complete marine and continental forearc in order to decipher down-dip and along-strike structural variations in the Sumatran subduction zone.

\section{Earthquake data}

For the local earthquake tomography we use data from a dense amphibious network of up to 62 stations covering the Sumatran forearc from the trench to the volcanic arc (Lange et al., 2010). The 52 land stations from SEIS-UK were in-
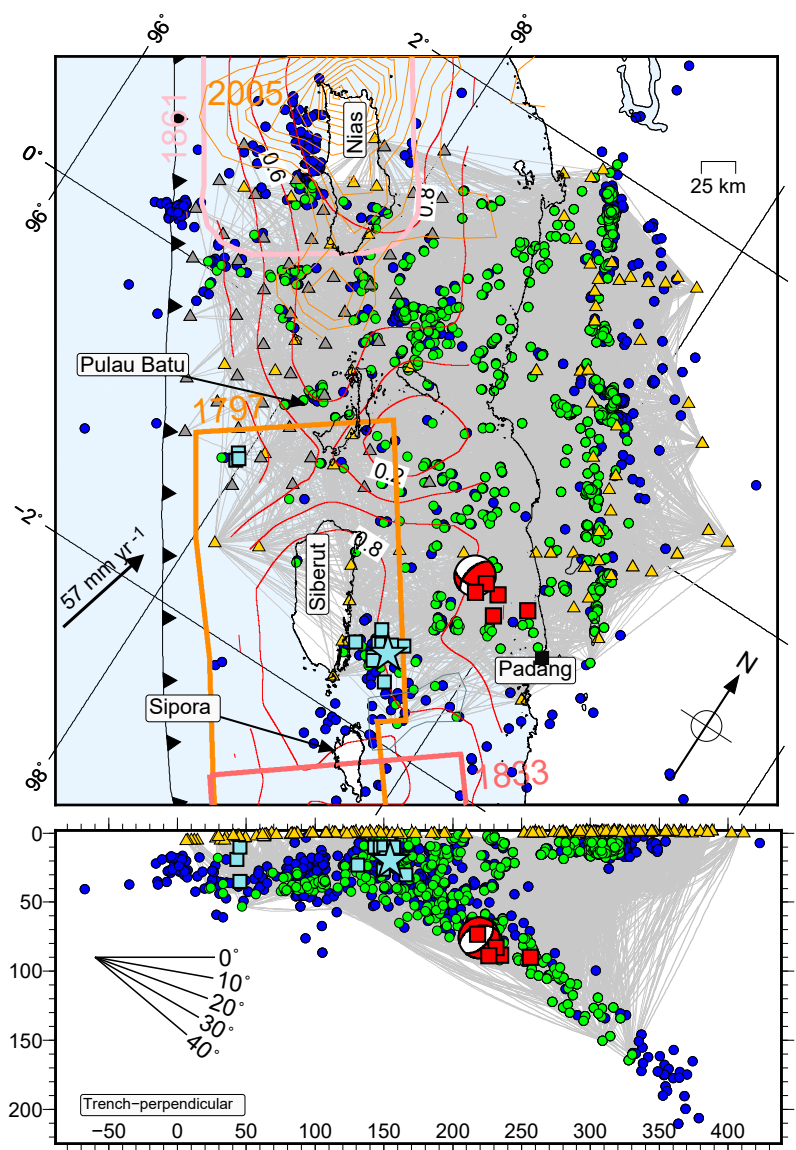

Figure 2. Station and event distribution, and ray coverage of the inversion. Green circles indicate events used in the inversion and corresponding ray paths are indicated by grey lines. Blue circles indicate the complete local catalogue (e.g., with events outside the network, or excluded for other reasons such as large RMS or a small number of picks per event). Yellow triangles (grey triangles for 2-week OBS deployment) indicate stations used in the study. The global Centroid-Moment-Tensor (gCMT) focal mechanism of the 30 September 2009 Padang earthquake and its aftershocks (McCloskey et al., 2010) are indicated in red. The plate coupling from Chlieh et al. (2008) is indicated with red contour lines and labeled with the coupling degree. Light blue squares show the events from the seismic crisis during 2008 occurring in a persistent seismicity cluster SE of Siberut Island (Wiseman et al., 2011), including the $M_{\mathrm{W}} 7.2$ main shock of 25 February (blue star). Other symbols as in Fig. 1.

stalled in April 2008 between $1.8^{\circ} \mathrm{S}$ and $1.8^{\circ} \mathrm{N}$ on the mainland and on the islands of Nias, Pulau Batu, Siberut and North Pagai. Offshore, the network was complemented by 10 three-component ocean-bottom seismometers (OBSs; Minshull et al., 2004) equipped with differential pressure gauges from June 2008 to February 2009. During October 2008, 10 land stations were removed from the Sumatran mainland, leaving the remaining 42 land stations until February 2009. The land stations continuously recorded three spa- 
tial components with sample rates of 50 and $100 \mathrm{~Hz}$. We also include data from eight permanent stations operated by BMKG (Meteorological and Geophysical Agency of Indonesia, http://www.bmkg.go.id, last access: 16 May 2010), GEOFON (http://geofon.gfz-potsdam.de/, last access: 29 April 2010; FDSN code 1G) and stations GSI and BKNI operated by the GEOFON network (FDSN network code GE; GEOFON Data Centre, 1993) in the analysis. Furthermore, we include five stations for strong events from a temporary deployment north of our project area (Stankiewicz et al., 2010; GEOFON network code 7A-2008; Ryberg and Haberland, 2008) and three stations from an adjacent temporary network to the south (Collings et al., 2012). Additionally, data from 46 ocean-bottom stations (OBS/H) from an active-source experiment offshore (25 May and 10 June 2008) were considered (Vermeesch et al., 2009). A summary of the stations can be found in the supplementary material of Lange et al. (2010), Table 1. The main sources of noise in the records were tree movement, rain due to the tropical environment and anthropogenic noise (e.g., traffic), affecting in particular the horizontal components. At the ocean-bottom stations, $S$ waves were very difficult to pick because, in addition to high noise levels, the onset of $S$ wave arrivals was usually poorly defined due to basement conversions.

From the original dataset (Lange et al., 2010) with 1271 events and 324781 manually picked arrival times (20251 $P$ and $12220 S$-onsets), we selected events with more than nine $P$ and four $S$ phase picks and RMS values smaller than $1.5 \mathrm{~s}$. Then, we removed all phase arrivals with residuals larger than $2 \mathrm{~s}$. Because of the large number of stations and events on or near the Sumatran fault zone (SFZ) we applied a stricter selection criteria for these crustal events (depths less than $\sim 20 \mathrm{~km}$ and distances of less than $35 \mathrm{~km}$ from the fault trace) by excluding events with less than 11 recording stations and RMS values greater than $1 \mathrm{~s}$. These selection criteria were chosen to improve the numerical balance of events from different parts of the study region (slab events: 9165 onsets, SFZ events: 7686 onsets). Finally, we ignored stations with less than 15 high-quality observations. OBS/H stations with high station residuals or dubious time corrections were not included in the inversion in order to be sure that all the observed travel times are accurate. After having checked the stability of the 2-D inversions exclusively with events within the network (largest azimuthal gap between azimuthally adjacent stations, gap $\leq 180^{\circ}$ ), events with gap $<200^{\circ}$ were included in the inversion. We carefully checked that the relaxation of the gap criterion to $200^{\circ}$ did not produce substantially different velocity models. Figure 2 shows the ray coverage with many paths criss-crossing in the central part of the model. The final dataset consists of 655 events with $9939 P$ - (therefrom 2626 with the highest quality, using the quality assignment of Lange et al., 2010) and $4859 S$-arrivals (626 with highest quality).

\section{Local earthquake tomography}

We invert 2-D and 3-D velocity models of the Sumatran subduction zone using local earthquake tomography (LET) techniques (Aki and Lee, 1976; Kissling, 1988) by applying the well-established inversion code SIMUL2000 (Thurber, 1983; Evans et al., 1994) for the simultaneous inversion of hypocentral parameters and velocity structure $\left(v_{\mathrm{p}}, v_{\mathrm{p}} / v_{\mathrm{s}}\right)$. The original algorithm by Thurber (1983) was subsequently modified and enhanced with new features (e.g., EberhartPhillips, 1986, 1993; Um and Thurber, 1987; Thurber and Eberhart-Phillips, 1999) and has been widely used for various LET studies (e.g., Graeber and Asch, 1999; DeShon and Schwartz, 2004; Haberland et al., 2009). For the inversion of the Sumatra data (located on both the Southern Hemisphere and the Northern Hemisphere) SIMUL2000 needed to be modified to operate across the Equator.

In the damped least-squares inversion, the velocity structure $v_{\mathrm{p}}$ and $v_{\mathrm{p}} / v_{\mathrm{s}}$ are inverted from the observed travel times. The velocity model is represented by velocity values specified on a rectangular grid of irregularly spaced nodes. The velocity for a given point within the grid is calculated by linearly interpolating the eight neighboring grid nodes. For a fast calculation of the path integral, Thurber (1983) implemented the ray tracer based on the "Approximate Ray Tracing" technique (ART). Receiver and source are connected with different circular arcs with varying radii and inclinations. Then, the 2-D circular arcs are perturbed in three dimensions to further minimize the travel time in an iterative process (Um and Thurber, 1987). Following common practice we applied a staggered inversion scheme starting with inversions for a one-dimensional model, followed by an inversion for a two-dimensional velocity model, and finally a 3-D inversion using the 2-D model as a starting model. For each inversion, the arrival times were weighted by their assigned pick uncertainties and all events were relocated prior to each iteration.

The importance of careful selection of the minimum 1-D model was described by various authors (e.g., Kissling, 1988; Eberhart-Phillips, 1990; Kissling et al., 1994). As 1-D $v_{\mathrm{p}}$ starting model, we used the "minimum one-dimensional model" from Lange et al. (2010) (Fig. 3, green line), which was obtained from a brute force search of different one-dimensional input models using the program VELEST (Kissling et al., 1994) and active source studies (Vermeesch et al., 2009). For the inversion of the 2-D velocity model we tested different $v_{\mathrm{p}}$ starting models from an active source refraction study (Vermeesch et al., 2009), from the seismicity study of Lange et al. (2010) and the LET of Collings et al. (2012) (Fig. 3). Based on these different velocity models the inversion of the 2-D $v_{\mathrm{p}}$ velocity model leads to very similar results. For the inversion of the 2-D $v_{\mathrm{p}} / v_{\mathrm{s}}$ model we fixed (i.e., highly damped) the $v_{\mathrm{p}}$ model and used a constant $v_{\mathrm{p}} / v_{\mathrm{s}}$ ratio of 1.77 derived from Wadati diagrams as starting model. 
Horizontal distances between nodes were $30 \mathrm{~km}$ in the trench-perpendicular direction ( $x$ axis) and, for the 3-D inversion, $50 \mathrm{~km}$ in the trench-parallel direction ( $y$ axis). In the vertical direction ( $z$ axis) node spacing is $10 \mathrm{~km}$ down to $50 \mathrm{~km}$ depth with one additional node at $5 \mathrm{~km}$ depth. Below $50 \mathrm{~km}$ depth, coarser node spacing is used with nodes at 70,90 , and $120 \mathrm{~km}$ depth to account for the decreasing ray coverage with depth. The grid is rotated relative to the trend of the north direction by $28^{\circ}$ and centered at $0^{\circ} \mathrm{N}, 99^{\circ} \mathrm{E}$. After carefully testing different spacing parameters for 2-D and 3 -D inversions in all three directions, we selected the node spacing as a compromise between resolution and stability of the inversion.

Following Evans et al. (1994), one additional node is introduced at all edges of the model with a much larger distance for computational reasons. The damping value of the damped least-squares inversion was carefully determined by "trade-off" curves between model variance and data variance (Eberhart-Phillips, 1986) and is chosen such as to simultaneously minimize the model variance and data variance. This is achieved by plotting model variance versus data variance of one-step inversions with different damping values for a given model geometry. SIMUL2000 uses one damping value for all inversion steps and the model and data variance for the trade-off curve is taken from the first inversion step. We made various inversions with different damping values and found that the spatial distribution of anomalies stays similar, but with varying amplitudes of the anomalies. The final 3-D inversion yields a significant reduction of the data variance. The $P$-wave data variance reduction is $76 \%$ compared to the minimum 1-D velocity model. The $S$-wave data variance reduction is only $18 \%$ compared to a homogeneous model with $v_{\mathrm{p}} / v_{\mathrm{s}}$ values of 1.77 . The small degree of improvement for the 3-D velocity model relates mostly to the high noise levels on the horizontal components resulting in $S$ onsets of low quality. We inverted 3-D velocity models for $v_{\mathrm{p}} / v_{\mathrm{s}}$ ratios and conducted extensive $3-\mathrm{D} v_{\mathrm{p}} / v_{\mathrm{s}}$ checkerboard tests, synthetic modeling and parameter tests. However, due to the low quality of $S$ onsets, the 3-D $v_{\mathrm{p}} / v_{\mathrm{s}}$ inversion was not robust and the data variance reduction was always small. Therefore we only discuss $v_{\mathrm{p}} / v_{\mathrm{s}}$ ratios of the 2 -D inversion.

\section{Resolution and uniqueness}

The method of LET tries to find a set of hypocenters and a velocity model, which jointly fit the arrival times best. Therefore, any LET code has some limitations, which include a finite number of synthetic recovery test and a partially subjective choice of parameterization (e.g., grid spacing) of the velocity model or the choice of the damping value. As discussed in the previous chapter, SIMUL2000 uses a fixed velocity grid definition and a constant damping value set according to finding a compromise between obtaining a good

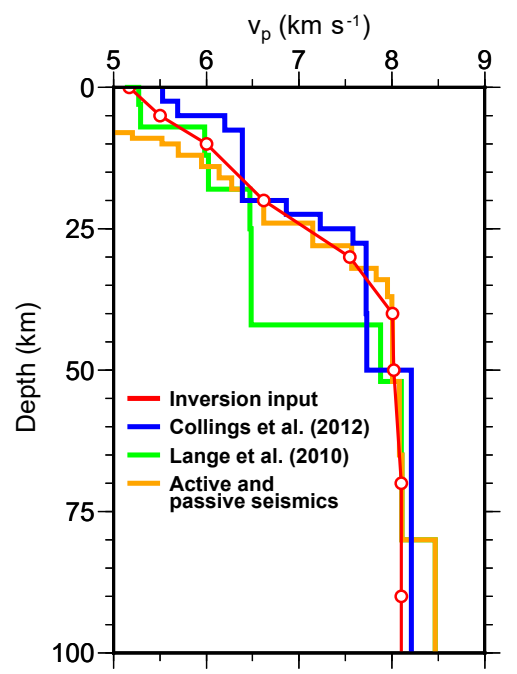

Figure 3. Velocity models used as starting model for the twodimensional tomographic inversion of $v_{\mathrm{p}}$ (red line and red circles). Because of the large number of stations and events on or near the SFZ, the minimum 1-D velocity model (green line) is dominated by the crustal structure of the Sumatran mainland. This velocity model is not appropriate for the events in the outer forearc, so we constructed a layered 1-D $v_{\mathrm{p}}$ velocity function based on an active source refraction study (Vermeesch et al., 2009). Above $30 \mathrm{~km}$ depth, we adopted a one-dimensional, staircase-like velocity-depth function based on an active source refraction study (Vermeesch et al., 2009, orange line); for depths greater than $30 \mathrm{~km}$ we adopted the one-dimensional velocity function from a minimum 1-D velocity model (Lange et al., 2010). The blue line shows the minimum 1-D $v_{\mathrm{p}}$ velocity model from Collings et al. (2012) for the region adjacent to the southeast of our study region but covering a similar part of the subduction system.

data fit with low model variance, as judged by a trade-off curve.

\subsection{Dependency of 2-D inversion on 1-D input model}

We tested the dependency of the 2-D inversion (constant values along the $y$ axis) on the 1-D input model in order to estimate the stability of the inversion and its ability to converge. This was done by constructing (realistic) randomized $v_{\mathrm{p}}$ velocity models with increasing velocity for increasing depths. These models were used as alternative starting models and the inversion was otherwise carried out identically. We also tested alternative $v_{\mathrm{p}}$ starting models from the active source refraction study of Vermeesch et al. (2009) and the minimum 1-D $v_{\mathrm{p}}$ model of Collings et al. (2012) (Fig. 3). We then carefully checked the dependency of the 2-D inversion on the velocity models and only found a minor dependency of the 1-D input model, indicating a very stable result of the 2-D inversion, which suggests a well-defined global minimum in the solution space for the 2-D inversion. The independence of the inverted 2-D velocity model on the 1-D input models alone does not necessarily point to a better imaging capacity of the 
model and might also be related to oversimplification of reality. We find this stability of the 2-D inversion for different velocity model parameterizations (lateral and depth spacing) and a wide range of 1-D $v_{\mathrm{p}}$ velocity input models. Furthermore, the following 3-D inversion only results in a modest further improvement of the fit. The trench-perpendicular velocity heterogeneity (2-D structure) is thus more important than trench-parallel heterogeneity (3-D structure).

\subsection{Spread value}

The spread function of the resolution matrix poses a possibility to assess the resolution of the model nodes. The spread function (e.g., Toomey and Foulger, 1989) summarizes the information contained in a single averaging vector or row of the full-resolution matrix. For a peaked resolution, i.e., low smearing, the diagonal element is much larger than the offdiagonal elements and the spread is low. The spread values (Fig. 4) show low values in the central part of the model between the SFZ and the islands with a reduced resolution in the region offshore Siberut and Nias. At depths larger than $50 \mathrm{~km}$, resolution is moderate as indicated by reduced spread values to $80 \mathrm{~km}$ depth. Below the Wadati-Benioff zone there is basically no penetration and thus no resolution at all.

\subsection{Checkerboard tests and synthetic recovery tests}

Synthetic tests and checkerboard tests were carried out to evaluate the resolution of the inversion. The procedure includes forward calculation of the travel times for a synthetic velocity model and the actual source and receiver distribution. In a second step, the calculated travel times are then perturbed with Gaussian noise, with a standard deviation dependent on the pick quality, from $0.05 \mathrm{~s}$ for the highest-quality observations to $0.2 \mathrm{~s}$ for the lowest-quality observations. Finally, the perturbed travel times are introduced into the inversion.

\subsubsection{2-D checkerboard tests}

The 2-D checkerboard tests were conducted for $v_{\mathrm{p}}$ and $v_{\mathrm{p}} / v_{\mathrm{s}}$ models (Fig. 5). We used varying block sizes in which the input models were perturbed by $\pm 5 \%$. At the highest resolution (blocks with one grid point dimension, equivalent to $30 \mathrm{~km}$ horizontal space and $10 \mathrm{~km}$ vertical space in the shallow part of the model), the pattern of perturbations is restored in the central part but the maximum amplitude of the recovered anomalies was $3.7 \%$, i.e., only about $75 \%$ of the input anomalies. The checkerboard tests with $2 \times 2$ blocks $(60 \times 20 \mathrm{~km})$ and lower resolution restore both the pattern and the amplitudes in the central part of the model and beneath the SFZ.

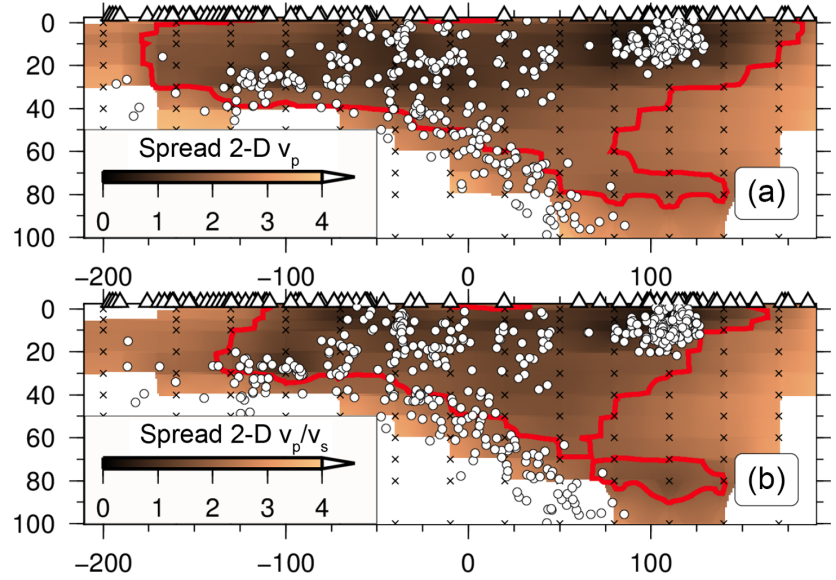

Figure 4. Spread values of 2-D $v_{\mathrm{p}}$ (a) and $v_{\mathrm{p}} / v_{\mathrm{s}}$ (b) inversion. Regions with low spread values and thus good resolution (selection of a cut-off spread value based on analysis of the model resolution matrix and synthetic tests) are encircled with a red line. Cut-off spread values are 2.1 and 1.9 for $v_{\mathrm{p}}$ and $v_{\mathrm{p}} / v_{\mathrm{s}}$, respectively. Circles indicate hypocenters and grid nodes are shown with crosses. Stations are indicated with triangles.

\subsubsection{3-D checkerboard test}

For the 3-D case we performed numerous checkerboard inversions using different checkerboard sizes. The checkerboard anomaly with 8 nodes $(2 \times 2 \times 2$ checkerboard, equivalent to $60 \times 100 \times 20 \mathrm{~km}$ ) is reconstructed in the central part at depths between 5 and $50 \mathrm{~km}$ (Fig. 6). Below $50 \mathrm{~km}$ only the region beneath the volcanic arc shows sufficient ray coverage, but the profile view suggests vertical smearing below $50 \mathrm{~km}$ depth. In general, the resolution is good between the forearc islands and the SFZ between 5 and $50 \mathrm{~km}$ for the region above the Wadati-Benioff zone, so we will restrict our interpretation to this depth range. The shallow $(<30 \mathrm{~km})$ region beneath the eastern part of Siberut is characterized by aseismic behavior during the deployment and the limited ray coverage results in insufficient recovery of the checkerboard in this region. A threshold for the spread values has been chosen to discriminate regions with high and low resolution and is superimposed on the resulting tomographic velocity models. The choice of threshold was carefully determined based on checkerboard tests, the ray coverage, and on the relative amplitudes of the spread values.

\subsection{3-D synthetic restoration test}

Restoring resolution tests were conducted to estimate the capacity of the data to resolve the geometry and amplitudes of potential velocity structures. We constructed synthetic $v_{\mathrm{p}}$ velocity models with similar characteristics in amplitude and dimensions as the inversion results and further models with velocity anomalies representing the subducted IFZ. A possibly modified crust along the IFZ was incorpo- 

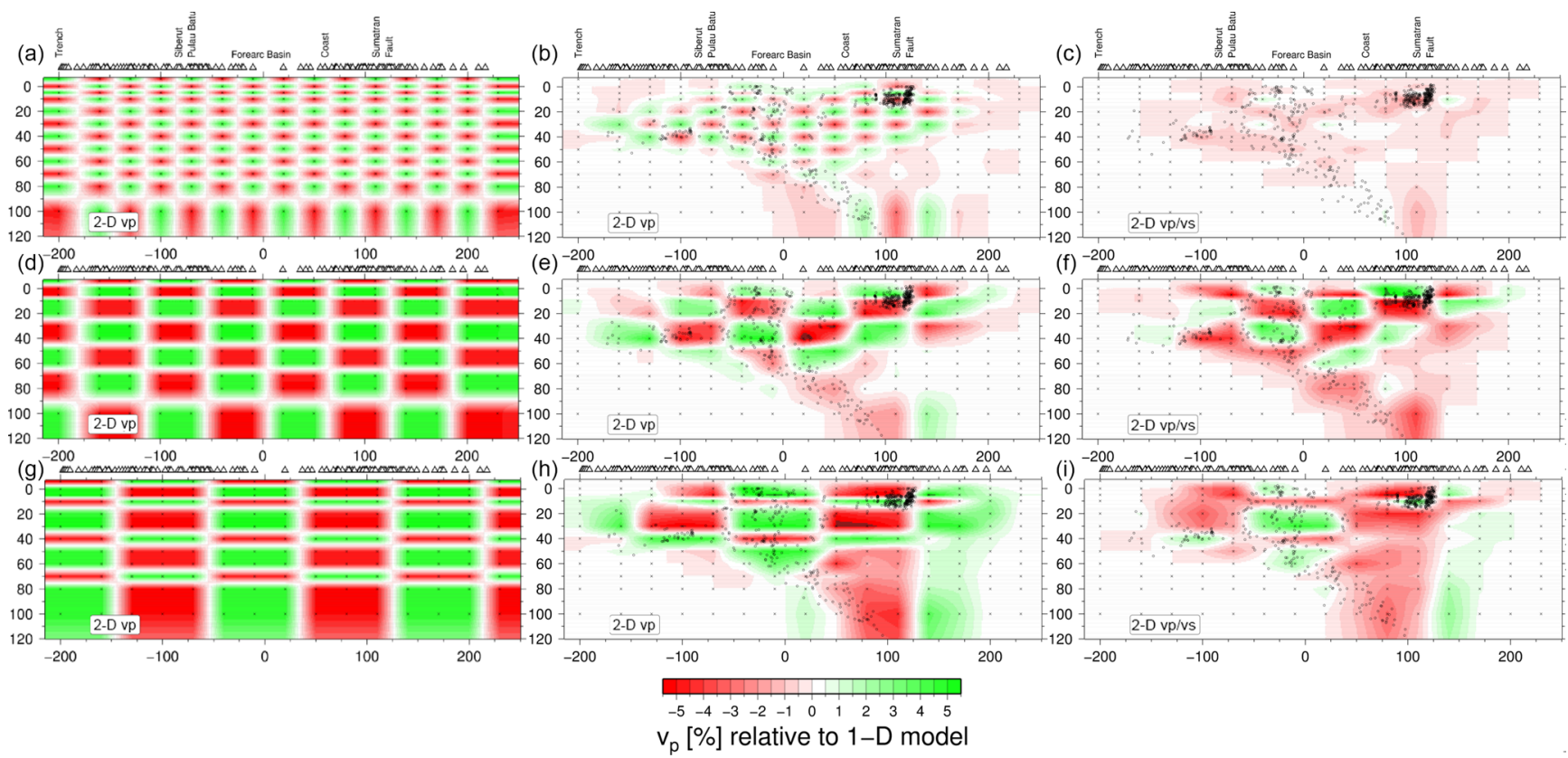

$v_{p}^{-5}[\%]$ relative to $1-D$ mode

Figure 5. 2-D synthetic checkerboard models with $5 \%$ velocity perturbation input anomalies (a, d, $\mathbf{g})$, the inversion restoration for $v_{\mathrm{p}}(\mathbf{b}, \mathbf{e}$, h) and $v_{\mathrm{p}} / v_{\mathrm{s}}(\mathbf{c}, \mathbf{f}, \mathbf{i})$ models. Crosses represent nodes used in the inversion and the reconstructions are plotted with the resulting hypocenter locations (black points). We calculated different checkerboard inversions using $1 \times 1$ and $2 \times 2$ (shown in the rows from top to bottom) grid node model perturbations. Noise was added to the synthetic data depending on the quality of the arrivals.

rated as obliquely oriented positive velocity anomalies at the expected position of the subducting crust (but with a larger thickness varying between 15 and $30 \mathrm{~km}$ ). Further tests were conducted with shallow velocity anomalies. Figure 7 shows the 3-D restoration of a synthetic model where we integrated different anomalies. The figure shows the restoration of an oblique velocity anomaly oriented in the direction of the subducted IFZ at $5 \mathrm{~km}$ depth and at depths from the plate interface and trench-parallel velocity anomalies at $30 \mathrm{~km}$ depth. The absolute values of $v_{\mathrm{p}}$ for the synthetic features are adequately reproduced (Fig. 7) in regions with good resolution as indicated by the spread value.

\section{Results and discussion}

The 2-D $v_{\mathrm{p}}$ and $v_{\mathrm{p}} / v_{\mathrm{s}}$ velocity model is shown in Fig. 8, and the final 3-D $v_{\mathrm{p}}$ velocity model is shown in Figs. 9 and 10 . In the following, we discuss the main features for the different tectonic units, making use of the lower-case labels in Figs. 9 and 10.

\subsection{Accretionary prism, forearc islands and forearc basin}

In the shallow part of the $v_{\mathrm{p}}$ velocity model we observe regions of reduced $v_{\mathrm{p}}$ velocities alternating with higher $v_{\mathrm{p}}$ values at shallow depths (Fig. 8, $10 \mathrm{~km}$ depth and Fig. 10a, $\mathrm{b}$ and $\mathrm{c}$ ). In the following, we discuss these regimes start- ing at the trench and moving towards the mainland of Sumatra. The accretionary wedge composes the frontal prism adjacent to the deep-sea trench as well as the lower to middle continental slope seaward of the forearc islands. The accretionary domain (labeled a in Figs. 9 and 10) is characterized by moderate velocities of $\sim 5 \mathrm{~km} \mathrm{~s}^{-1}$ down to a depth of $\sim 15 \mathrm{~km}$, increasing to $\sim 6 \mathrm{~km} \mathrm{~s}^{-1}$ above the landwarddipping high-velocity zone (labeled f, Fig. 10). Velocities in the upper $15 \mathrm{~km}$ increase underneath the forearc islands (labeled b) with values of $\sim 6 \mathrm{~km} \mathrm{~s}^{-1}$, which are also observed beneath the coast. The forearc basin between the islands and the mainland (labeled c) shows moderately low velocities of $\sim 5 \mathrm{~km} \mathrm{~s}^{-1}$ down to $10 \mathrm{~km}$ depth. When considering the shallow forearc structure $(<15 \mathrm{~km})$, the trenchperpendicular shallow structure variations are similar to the results of Collings et al. (2012) for the southern Mentawai Islands, in a way that the slow and fast domains alternate in the landward direction. The most obvious difference is that Collings et al. (2012) found low velocity values of approximately $5 \mathrm{~km} \mathrm{~s}^{-1}$ beneath the Mentawai forearc islands (Sipora, North Pagai and South Pagai), adjacent to faster material beneath the forearc basin. Our results image the region beneath the forearc islands as a trench-parallel (labeled b, Figs. 10 and 11), elongated zone of increased velocities, sandwiched between the relatively lower velocities of the trenchward accretionary prism (labeled a, Figs. 10 and 11) and the landward forearc basin (labeled c) the fast velocity anomalies below and between the islands might be inter- 


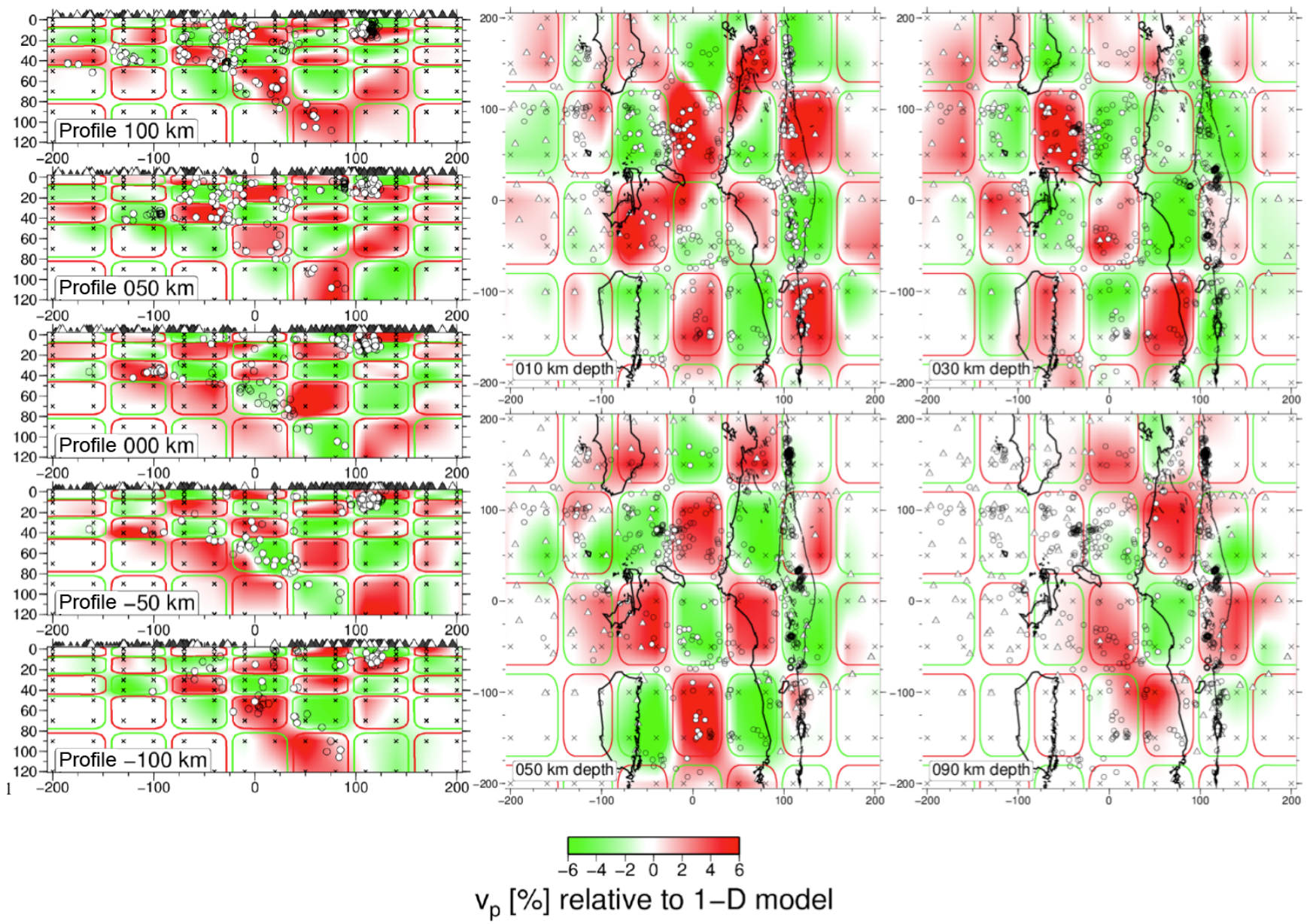

Figure 6. 3-D synthetic checkerboard models with $5 \%$ velocity perturbation input anomalies and the inversion restoration for the 3 -D $v_{\mathrm{p}}$ model. Other symbols as in Fig. 5.

preted as occurrence of faster accreted IFZ material beneath the Batu Islands. On geological timescales the intersection of the IFZ with the marine forearc migrates southeast as the subducted plate descends, and thus might have created marginparallel accreted features north of the current intersection of the IFZ with the trench (e.g., north of Siberut island). However, we cannot find significant along-strike variations in $v_{\mathrm{p}}$ between the Mentawai Islands and the trench (e.g., labeled a in Figs. 10 and 11), which might equally be explained by accretion of seamounts (Fig. $1 ; 4.5^{\circ} \mathrm{S}, 99.5^{\circ} \mathrm{E}$ ).

The very shallow marine forearc at depths of $5 \mathrm{~km}$ is characterized by three regions of relatively reduced $v_{\mathrm{p}}$ velocities of between 5 and $6 \mathrm{~km} \mathrm{~s}^{-1}$. Faster regions $\left(\sim 6 \mathrm{~km} \mathrm{~s}^{-1}\right)$ are spatially related to the forearc islands Nias, Pulau Batu, Siberut, and Pulau Pini (Fig. 9b). In-between the forearc islands the marine forearc is mostly characterized by $v_{\mathrm{p}}$ velocities of $5 \mathrm{~km} \mathrm{~s}^{-1}$.

At depths of $20-30 \mathrm{~km}$ and $25 \mathrm{~km}$ east of the Mentawai Fault, a trench-parallel velocity anomaly of higher $v_{\mathrm{p}}$ velocities (labeled d in Figs. 9 and 10, indicative by the up- welling of contour lines) suggests a shallower location of the Moho beneath the forearc basin and hence a reduced thickness of the overriding crust. Alternatively, this velocity anomaly might reflect a deep subducted seamount. Based on reflection data Singh et al. (2011) image an undulation of the top of the subducting slab in the Sumatran forearc to the south at $5^{\circ} \mathrm{S}$ and interpreted this as a subducted seamount. We exclude the possibility of a subducted seamount due to the size of the anomaly $(200 \mathrm{~km} \times 80 \mathrm{~km})$ and the absence of a similar feature in the seismicity (Fig. 1). Alternatively, this trench-parallel velocity anomaly of higher $v_{\mathrm{p}}$ velocities (labeled d) might be explained by an accreted mafic block.

\subsection{Sumatran fault zone (SFZ) and volcanic arc}

While the offshore forearc is made up of young sediments from the Eocene to Holocene, the mainland shows a $\sim 130 \mathrm{~km}$ wide belt of different rock units along the SFZ. The SFZ is characterized by high seismicity rates (e.g., Weller et al., 2012) due to stress and strain partitioning from the oblique subduction (McCaffrey et al., 2000). This belt is 


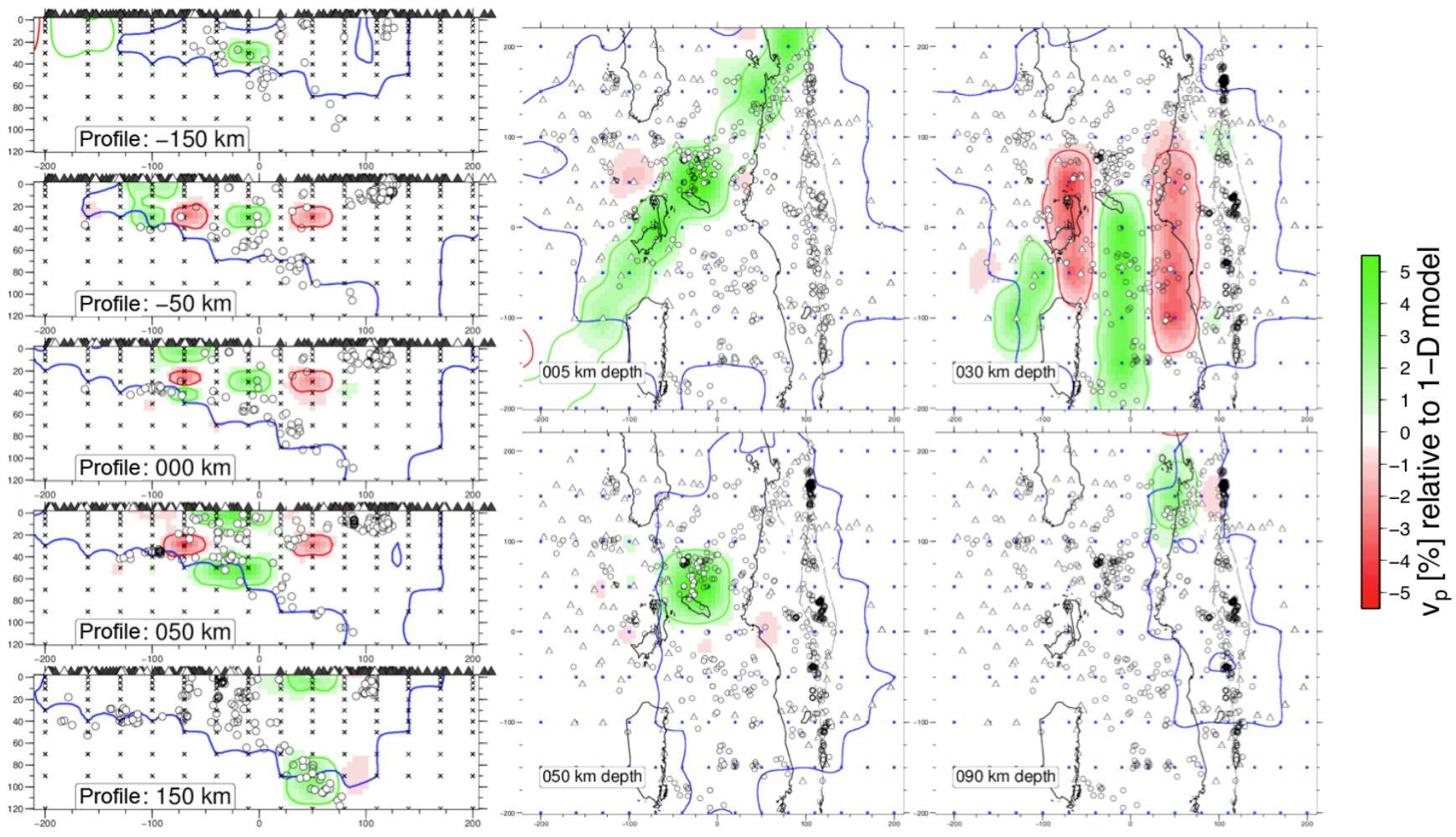

Figure 7. 3-D synthetic models with $5 \%$ velocity $v_{\mathrm{p}}$ perturbation input anomalies and the inversion restoration. The model consists of northsouth trending anomalies (map view $30 \mathrm{~km}$ depth) and a NE-SW trending low velocity anomaly for both the shallow part of the model in $5 \mathrm{~km}$ and for the trace of the subducted IFZ. Red and green lines indicate the $5 \%$ contour lines of the input anomalies. The blue lines encircle regions with good resolution defined by the spread value. Other symbols as in Fig. 5.

mostly composed of Permian to Jurassic sedimentary rocks, Eocene volcanic rocks and Jurassic to Eocene intrusive units (Crow and Barber, 2005). The 3-D velocity model along the SFZ is characterized by only minor changes in $v_{\mathrm{p}}$ along strike. Seismic velocities of $7.8 \mathrm{~km} \mathrm{~s}^{-1}$ (indicative of continental Moho) are reached at depths larger than $30 \mathrm{~km}$ and outside the region of good resolution. A Moho depth between 28 and $40 \mathrm{~km}$ is inline with Moho depths from receiver functions in the region of the caldera of Lake Toba (Fig. 1; Sakaguchi et al., 2006; Kieling et al., 2011) and similar to the Moho depths inferred from receiver functions (Gunawan et al., 2011).

$v_{\mathrm{p}} / v_{\mathrm{s}}$ values beneath the SFZ (depths $\leq 20 \mathrm{~km}$ ) are between 1.65 and 1.72 (Fig. 8) and similar to the minimum 1-D velocity model of Weller et al. (2012), which used the same stations to derive an optimum 1-D model for the SFZ region only. These low $v_{\mathrm{p}} / v_{\mathrm{S}}$ ratios seem to be characteristic for the shallow crust in the region of the SFZ. Muksin et al. (2013) conducted a LET for the shallow crust $(<15 \mathrm{~km})$ at $2^{\circ} \mathrm{N}$ and found similar lower $v_{\mathrm{p}} / v_{\mathrm{s}}$ values away from the SFZ. Equally, Koulakov et al. (2009) imaged predominantly lower $v_{\mathrm{p}} / v_{\mathrm{S}}$ ratios below 1.8 for the region $100 \mathrm{~km}$ northwest of our study area (labeled Tb in Fig. 1). Our findings differ from the velocity model of Koulakov et al. $(2009,2016)$, in that we find only weak indications of a patchy low-velocity zone beneath the magmatic arc at $30 \mathrm{~km}$ depth only.

\subsection{Subducting oceanic lithosphere}

Where the slab is still in contact with the overriding plate, the oceanic Moho is imaged as the inclined $7.8 \mathrm{~km} \mathrm{~s}^{-1} v_{\mathrm{p}}$ contour line (Figs. 8c and 10f). The plate interface, inferred from seismicity, is located at approximately $25 \mathrm{~km}$ depth below the forearc islands (Fig. 8), a little deeper than beneath the Pagai Islands at $3^{\circ} \mathrm{S}$, where it was found at $20 \mathrm{~km}$ depth (Collings et al., 2012), but significantly deeper than the plate interface from seismicity and refraction seismicity found at $15 \mathrm{~km}$ depth beneath Simeulue Island at $2.5^{\circ} \mathrm{N}$ (Tilmann et al., 2010; Shulgin et al., 2013).

Seismicity $25 \mathrm{~km}$ west of Nias (Fig. 2) is part of a coastparallel band of seismicity. This band of high seismicity corresponds to the transition between regions of significant coseismic (down-dip) and aseismic slip (up-dip) of the 2005 earthquake (Hsu et al., 2006) and extends northwestwards until Simeulue Island, roughly following the $500 \mathrm{~m}$ isobath contour lines (Tilmann et al., 2010). The depth variations in seismicity along this seismicity band suggest that the seismicity transition from aseismic to seismic behavior in the down-dip direction (Lange et al., 2007, 2010; Tilmann et al., 


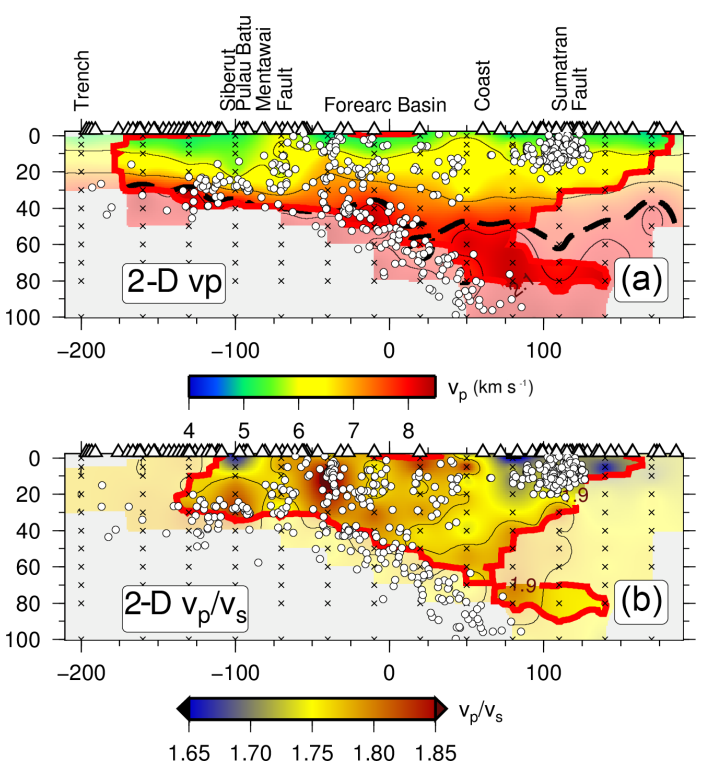

Figure 8. 2-D tomographic velocity models for $v_{\mathrm{p}}$ (a) and $v_{\mathrm{p}} / v_{\mathrm{S}}(\mathbf{b})$ models (profile direction is trench perpendicular). Regions with good resolution are encircled with a red line. Circles indicate hypocenters and grid nodes are shown with crosses. Stations are indicated with triangles. The dashed line in panel (a) indicates the $v_{\mathrm{p}} 7.8 \mathrm{~km} \mathrm{~s}^{-1}$ contour line and is used as a proxy for the Moho.

2010) might not be controlled by depth and hence lithostatic pressure.

The inclination of the subducting plate is approximately $25^{\circ}$ within the depth range between 40 and $80 \mathrm{~km}$, also based on the seismicity, as the resolution and grid spacing is insufficient for imaging subducting oceanic crust. There are hints of the contrast between the subducting high-velocity slab and the mantle wedge in the form of a dipping velocity contour (e.g., Fig 10d), but it is only imaged in a patchy way at the limit of the resolved area. At larger depths, seismicity can be traced down to $220 \mathrm{~km}$ with an inclination of approximately $36^{\circ}$ (Lange et al., 2010) but the velocity structure is no longer resolved (Fig. 9e).

Figure $9 \mathrm{f}$ shows a section through the $3-\mathrm{D} v_{\mathrm{p}}$ velocity model following the plate interface (defined by the SLAB1.0 model; Hayes et al., 2012). The dominant feature in this panel is the contrast between crust and mantle, allowing us to identify the position of the toe of the mantle wedge just landward of the forearc islands (except Pulau Pini, which is already well above the mantle wedge). No obvious alongstrike change can be identified in the mantle wedge. In particular, the velocity model does not reveal indications of velocity anomalies in the direction of the subducted IFZ, although the trace of the subducted IFZ is reflected by seismicity down to $~ 200 \mathrm{~km}$ depths (Fauzi et al., 1996; Lange et al., 2010); in Fig. 9f it is visible as a band of seismicity striking north (i.e., to top right in the figure) from Pulau Batu. The synthetic restoration tests (Fig. 7) document that the inversion is capable to resolve a $\sim 40 \mathrm{~km}$ wide velocity anomaly, if there would be any. Considering such large-scale structures, we conclude that the subducted IFZ did not disturb the velocity structure at depths of the plate interface, e.g., by releasing fluids and enhancing melt production. However, the IFZ clearly had a significant impact on the rheological conditions within the slab since it enhances intermediate depth seismicity down to large depths (Lange et al., 2010). Some of the events, labeled with $\mathrm{f}$ in Fig. 10, panel (c) are located 10-15 km below the plate interface defined by the global slab model (Hayes et al., 2012). Based on their hypocentral depths we interpret them as being spatially related to the oceanic crust to mantle transition (e.g., near the oceanic Moho) or even possibly occurring in the uppermost oceanic mantle. For the North Chilean subduction zone, Bloch et al. (2014) found a similar group of events $\sim 8 \mathrm{~km}$ below the plate interface for the North Chilean subduction zone and at depths between 30 and $60 \mathrm{~km}$ and proposed them to be spatially related to the oceanic Moho.

\section{$5.4 v_{\mathrm{p}} / v_{\mathrm{s}}$ model of the forearc}

As discussed in Sect. $2 S$ onsets are of lower quality due to tropical conditions and anthropogenic noise. Therefore, we only present the 2-D $v_{\mathrm{p}} / v_{\mathrm{s}}$ inversion results (Fig. 8b). In our study region around Nias and Siberut, we only find mostly moderately elevated $v_{\mathrm{p}} / v_{\mathrm{s}}$ values (up to 1.85 , Fig. $8 \mathrm{~b}$ ), whereas Collings et al., 2012 find strongly elevated $v_{\mathrm{p}} / v_{\mathrm{s}}$ values (up to 2.0) down to the plate interface below the $\mathrm{Pa}$ gai Islands. The largest values are found west of the forearc basins in the region of the Mentawai Fault just landward of the forearc islands. Since rays of the 2-D $v_{\mathrm{p}} / v_{\mathrm{s}}$ velocity model mostly sample the region northeast of Pulau Batu (Fig. 2) this likely reflects a local $v_{\mathrm{p}} / v_{\mathrm{s}}$ anomaly close to the Equator rather than being a feature present along the whole along-strike length of the study region. The reason for this region of elevated $v_{\mathrm{p}} / v_{\mathrm{s}}$ remains enigmatic. Possible explanations include fluids related to pathways created by the Mentawai Fault or structural differences due to subducted material from the IFZ. Although $v_{\mathrm{p}} / v_{\mathrm{s}}$ ratios are moderately elevated (up to 1.85) we cannot identify large-scale alteration of the mantle wedge due to surplus liquids from a strongly hydrated IFZ because serpentinized material is characterized by clearly elevated $v_{\mathrm{p}} / v_{\mathrm{s}}$ and reduced $v_{\mathrm{p}}$ values (e.g., Carlson and Miller, 2003). Because mantle serpentinization favors aseismic sliding and is related to the down-dip extent of the seismogenic zone (e.g., Hyndman et al., 1997; Oleskevich et al., 1999), the lack of large-scale serpentinization could explain why the seismogenic plate interface extends into the forearc mantle off Sumatra (e.g., Simoes et al., 2004; Collings et al., 2012). In particular, the stalling of the 2005 rupture was suggested to be limited by the subducted IFZ and reduced coupling of the plate interface (Fig. 2 and Chlieh et al., 2008) and might be related to rheological properties and heterogeneities along the plate interface. Based on multi- 


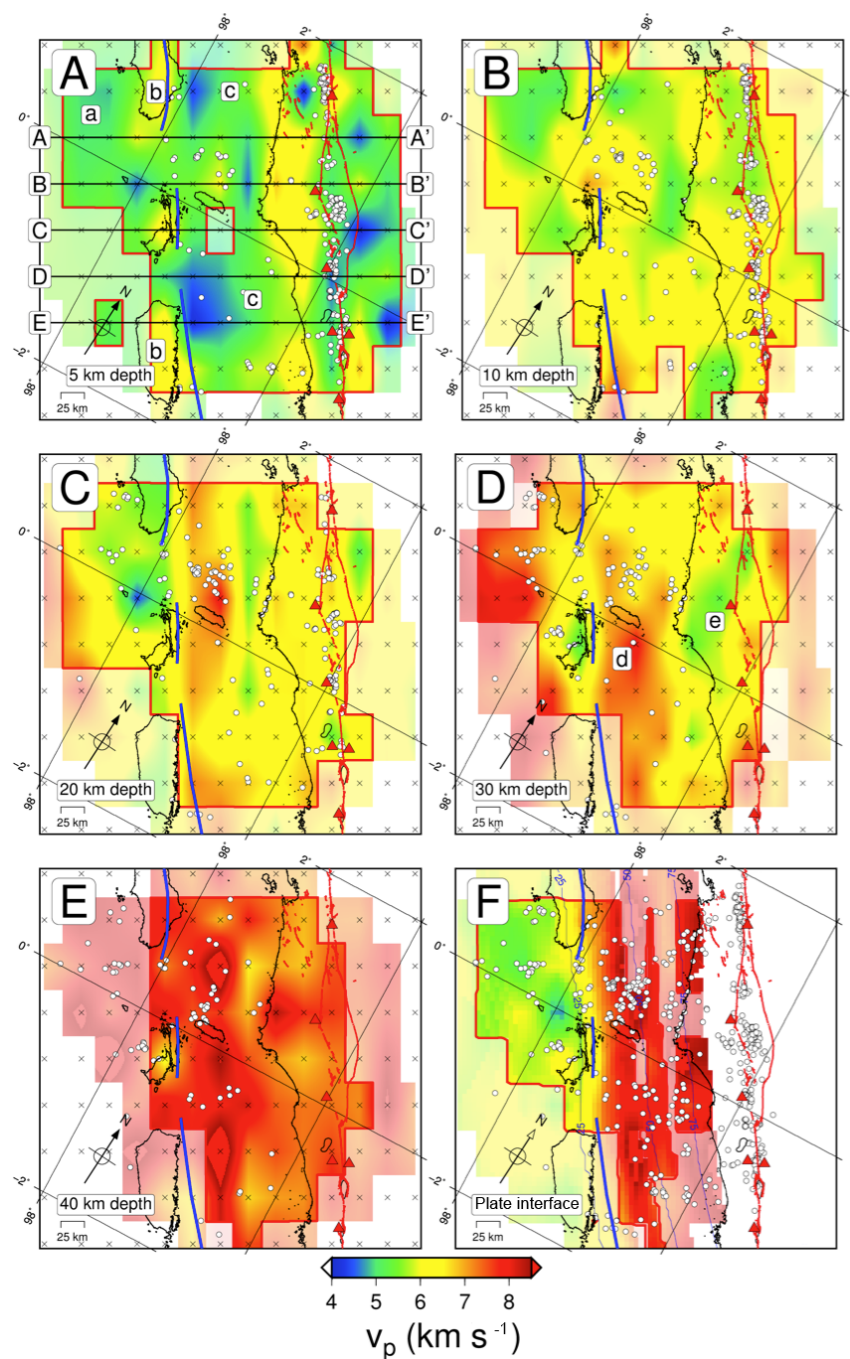

Figure 9. The 3-D $v_{\mathrm{p}}$ model: depth sections (a-e) and curved section along the plate interface as defined by the global SLAB1.0 model (Hayes et al., 2012) (f). Red lines encircle regions of good resolution defined by a cut-off spread value of 1.5 . White circles indicate events within $10 \mathrm{~km}$ of the section depth, except (f), where all events used for the inversion are shown. Volcanoes (Smithsonian Institute) shown with red triangles. The Mentawai Fault (blue line offshore) and the Sumatran Fault (red line onshore) are also shown. See text for explanation of characters. Other symbols as in Fig. 6.

channel seismic data, Henstock et al. (2016) identified an isolated $3 \mathrm{~km}$ basement high close to the 2005 slip termination as well as along-strike variations of basement relief. Such features are large enough to affect the rheological behavior of the plate interface such as coupling but are below the resolution of our LET.
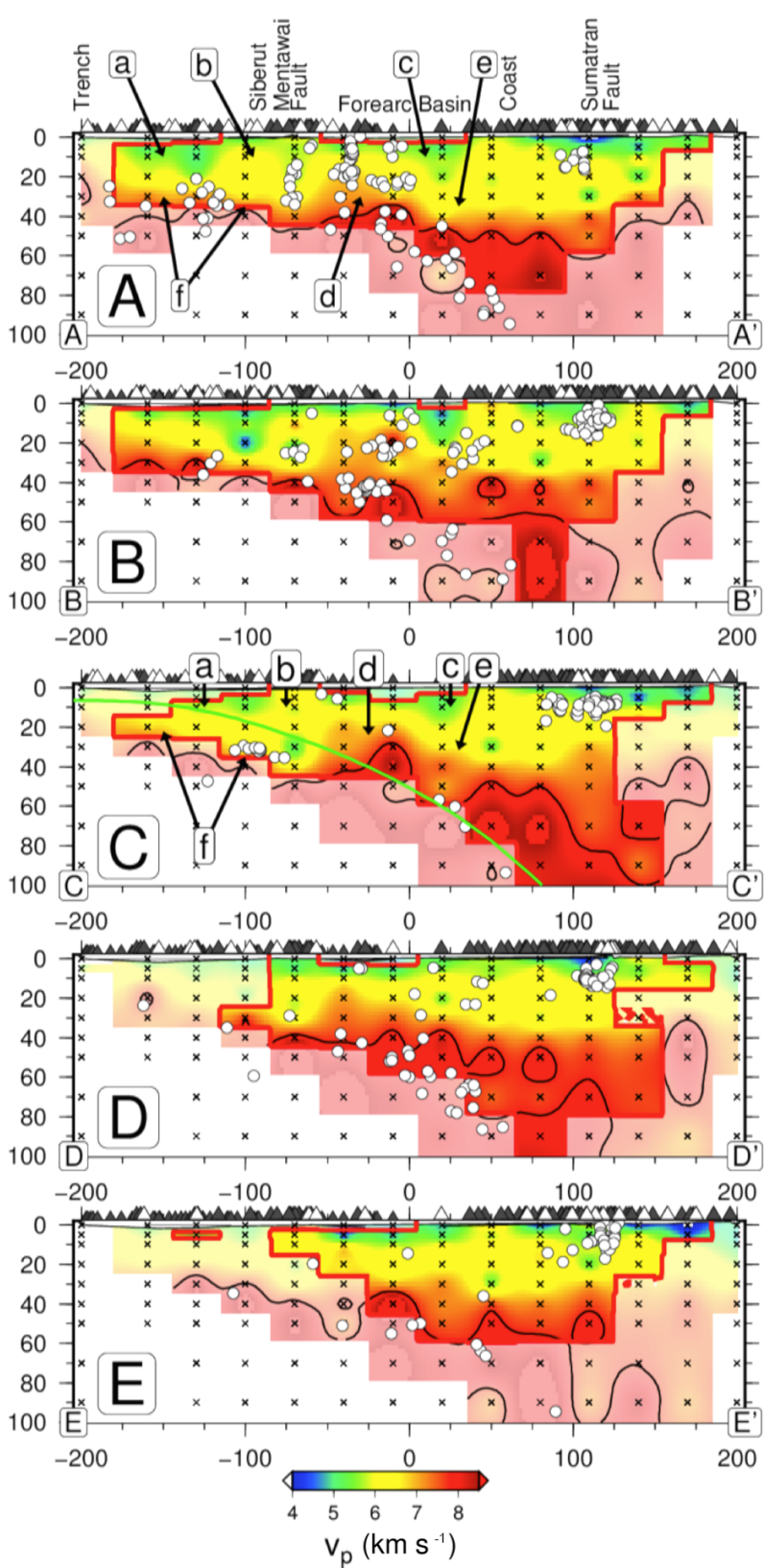

Figure 10. Cross sections along trench-perpendicular trending profiles through the 3-D $v_{\mathrm{p}}$ model. See Fig. 9a for location of cross sections. White circles indicate events within $10 \mathrm{~km}$ of the profile and stations closer than $25 \mathrm{~km}$ to the profile are shown by white triangles, the remaining ones by black triangles. The 46 OBS stations of the 2-week deployment are shown with smaller triangles. Grid nodes are shown with crosses. Red lines encircle regions of good resolution defined by a cut-off spread value of 1.5. Green line in panel (c) indicates the plate interface as defined by the global SLAB 1.0 model (Hayes et al., 2012). The $7.8 \mathrm{~km} \mathrm{~s}^{-1} v_{\mathrm{p}}$ contour line is indicated by a black line. See text for explanation of characters. Other symbols as in Fig. 6. Note that the geographic labels at the top refer to all profiles, but that only profiles $\mathrm{C}$ (Batu Islands) and $\mathrm{E}$ (Siberut) actually cross a forearc island. 


\section{Conclusions}

We present 2-D and 3-D velocity models from a local earthquake tomography (LET) using data from a dense network of seismic stations covering the onshore and offshore domain of the northern Sumatra forearc close to the Equator. The models resolve the structure of the forearc including the accretionary prism, forearc islands, the forearc basin, the mantle wedge and the volcanic arc down to a maximum depth of $\sim 60 \mathrm{~km}$. The down-going slab is traced by inclined velocity contour lines at depths $<40 \mathrm{~km}$. The oceanic crust has a velocity of $\sim 7 \mathrm{~km} \mathrm{~s}^{-1}$ and is located at a depth of $\sim 25 \mathrm{~km}$ beneath the forearc islands (based on the seismicity depth distribution). $v_{\mathrm{p}}$ velocities beneath the magmatic arc, which spatially coincides with the SFZ, are around $5 \mathrm{~km} \mathrm{~s}^{-1}$ at $10 \mathrm{~km}$ depth and the $v_{\mathrm{p}} / v_{\mathrm{s}}$ ratios in the uppermost $10 \mathrm{~km}$ are low, indicating the presence of felsic lithologies typical for continental crust.

The forearc basins west and east of the Mentawai Islands are characterized by velocities of $\sim 5 \mathrm{~km} \mathrm{~s}^{-1}$ down to $15 \mathrm{~km}$ depth. Although the region is characterized by the subducted IFZ, which influences seismicity down to depths of $200 \mathrm{~km}$, the 3-D velocity model at depths of the plate interface shows prevailing trench-parallel structures suggesting that the subducted IFZ did not significantly modify the velocity structure at seismogenic depths. At very shallow depths $(\sim 5 \mathrm{~km})$ and below the forearc islands (Pulau Batu, Siberut, Nias) higher $v_{\mathrm{p}}$ velocities of $\sim 6 \mathrm{~km} \mathrm{~s}^{-1}$ are found.

AT depths of $20-30 \mathrm{~km}$ and $\sim 25 \mathrm{~km}$ east of the Mentawai Fault, a trench-parallel velocity anomaly of higher $v_{\mathrm{p}}$ velocities might suggest a shallower location of the Moho beneath the forearc basin and hence a reduced thickness of the overriding crust.

Elevated $v_{\mathrm{p}} / v_{\mathrm{s}}$ ratios of 1.85 are found in the overriding crust in the region of the Mentawai Fault, which might be related to fluids. However, $v_{\mathrm{p}} / v_{\mathrm{s}}$ ratios are still too small to support a large-scale serpentinization of the continental mantle and could explain why the seismogenic plate interface (observed as a locked zone from geodetic data) extends below the continental forearc Moho in Sumatra.

Data availability. Seis-UK data are available from IRIS (https: //www.iris.edu) using the network code ZB (2007-2009) (Lange et al., 2010). The GEOFON data with network codes GE and 7A (2008) (GEOFON Data Centre, 1993) are stored at the GEOFON data centre (https://geofon.gfz-potsdam.de/). GFZ instruments were provided by the Geophysical Instrument Pool Potsdam (GIPP). The data from the permanent Indonesian network (network code IA) are stored at BMKG (http://www.bmkg.go.id, last access: 16 May 2010).

Author contributions. DL, FT, TH, AR and DH were involved in the installation of the seismological stations. FT, TH, AR and DH designed the experiment. AR and DH supervised the project. DL processed the data, conducted the inversions and prepared the artwork. DL led the development of the manuscript supported by significant contributions from FT, TH and HK who contributed to the ideas, concepts and interpretation presented in this manuscript.

Competing interests. The authors declare that they have no conflict of interest.

Acknowledgements. We thank the SeisUK facility in Leicester for the loan of the instruments and the logistic support during this project, loan 828 (Brisbourne, 2012). We acknowledge the support of the colleagues at Geoteknologi LIPI for this project. LIPI-EOS let us share some of the sites of the SuGaR GPS network. We thank the captain and crew of the vessel Andalas for excellent work in the field. Furthermore, we thank the master and crew of R/V SONNE cruises SO-198 and SO-200 for the deployment and recovery of the OBS. OBS instruments were provided by OBIF. We thank Lisa C. McNeill and Penny Barton who participated in the acquisition of the OBS data. The project was funded by NERC (NE/D00359/1). EOS (Earth Observatory of Singapore) is thanked for supporting logistical costs of deployment on Mentawai and Batu Islands. We thank the Indonesian BMKG and German GEOFON for the station data from their permanent networks. Furthermore, we are indebted to all field crews for their excellent work under tropical conditions. We thank Imam Suprihanto, Bambang Suwargadi and Rachel Collings for support during the fieldwork. Finally, we gratefully acknowledge the cooperation of many Sumatran landowners, communities, and institutions for support and for allowing us to install the seismic stations on their property. Our special thanks go to Sylvain Barbot, Ivan Koulakov and an anonymous reviewer for their constructive comments and suggestions.

Edited by: Tarje Nissen-Meyer

Reviewed by: Ivan Koulakov and one anonymous referee

\section{References}

Aki, K. and Lee, W. H. K.: Determination of three-dimensional velocity anomalies under a seismic array using first Parrival times from local earthquakes, 1. A homogeneous initial model, J. Geophys. Res., 81, 4.381-4.399, https://doi.org/10.1029/JB081i023p04381, 1976.

Becker, J. J., Sandwell, D. T., Smith, W. H. F., Braud, J., Binder, B., Depner, J., Fabre, D., Factor, J., Ingalls, S., Kim, S-H., Ladner, R., Marks, K., Nelson, S., Pharaoh, A., Sharman, G., Trimmer, R., VonRosenburg, J., Wallace, G., and Weatherall, P.: Global Bathymetry and Elevation Data at 30 Arc Seconds Resolution: SRTM30_PLUS, Mar. Geod., 32, 355-371, https://doi.org/10.1080/01490410903297766, 2009.

Bilek, S. L., Engdahl, E. R., DeShon, H. R., and El Hariri, M.: The 25 October 2010 Sumatra tsunami earthquake: Slip in a slow patch, Geophys. Res. Lett., 38, L14306, https://doi.org/10.1029/2011GL047864, 2011.

Bloch, W., Kummerow, J., Salazar, P., Wigger, P., and Shapiro, S. A.: High-resolution image of the North Chilean subduction zone: 
seismicity, reflectivity and fluids, Geophys. J. Int., 197, 17441749, https://doi.org/10.1093/gji/ggu084, 2014.

Brisbourne, A.: How to store and share geophysical data, Astron. Geophys., 53, 4.19-4.20, 2012.

Cande, S. C., LaBrecque, J. L., Larson, R. L., Pitman, W. C., Golovchenko, X., and Haxby, W. F.: Magnetic lineations of World's Ocean Basins (one chart), Amer. Ass. Petrol. Geol., Tulsa, 1989.

Carlson, R. L. and Miller, D. J.: Mantle wedge water contents estimated from seismic velocities in partially serpentinized periodites, Geophys. Res. Lett., 30, 1250, https://doi.org/10.1029/2002GL016600, 2003.

Chlieh, M., Avouac, J.-P., Hjorleifsdottir, V., Song, T.-R. A., Ji, C., Sieh, K., Sladen, A., Hebert, H., Prawirodirdjo, L., Bock, Y., and Galetzka, J.: Coseismic Slip and Afterslip of the Great $M_{\mathrm{W}} 9.15$ Sumatra-Andaman Earthquake of 2004, B. Seismol. Soc. Am., 97, S152-S173, https://doi.org/10.1785/0120050631, 2007.

Chlieh, M., Avouac, J. P., Sieh, K., Natawidjaja, D. H., and Galetzka, J.: Heterogeneous coupling of the Sumatran megathrust constrained by geodetic and paleogeodetic measurements, J. Geophys. Res., 113, B05305, https://doi.org/10.1029/2007JB004981, 2008.

Collings, R. E., Lange, D., Rietbrock, A., Tilmann, F., Natawidjaja, D. H., Suwargadi, B., Miller, M., and Saul, J.: Structure and seismogenic properties of the Mentawai segment of the Sumatra subduction zone revealed by local earthquake travel time tomography, J. Geophys. Res., 117, B01312, https://doi.org/10.1029/2011JB008469, 2012.

Crow, M. J. and Barber, A. J: Map: Simplified geological map of Sumatra Geological Society, London, Memoirs, 2005, 31:NP, https://doi.org/10.1144/GSL.MEM.2005.031.01.17, 2005.

Dean, S. M., McNeill, L. C., Henstock, T. J., Bull, J. M., Gulick, S. P. S., Austin, J. A., Bangs, N. L. B., Djajadihardja, Y. S., and Permana, H.: Contrasting Décollement and Prism Properties over the Sumatra 2004-2005 Earthquake Rupture Boundary, Science, 329, 207-210, https://doi.org/10.1126/science.1189373, 2010.

DeShon, H. R. and Schwartz, S. Y.: Evidence for serpentinization of the forearc mantle wedge along the Nicoya Peninsula, Costa Rica, Geophys. Res. Lett, 31, L21611, https://doi.org/10.1029/2004GL021179, 2004.

Dessa, J. X., Klingelhoefer, F., Graindorge, D., Andre, C., Permana, H., Gutscher, M. A., Chauhan, A., and Singh, S. S.: Megathrust earthquakes can nucleate in the forearc mantle: Evidence from the 2004 Sumatra events, Geology, 37, 659-662, https://doi.org/10.1130/G25653A.1, 2009.

Diament, M., Harjono, H., Karta, K., Deplus, C., Dahrin, D., Zen, M. T., Gérard, M., Lassal, O., Martin, A., and Malod, J.: Mentawai fault zone off Sumatra: A new key to the geodynamics of western Indonesia, Geology, 20, 259-262, 1992.

Eberhart-Phillips, D.: Three-dimensional structure in northern California coast ranges from inversion of local earthquake arrival time, B. Seismol. Soc. Am., 76, 1.025-1.052, 1986.

Eberhart-Phillips, D.: Three-Dimensional P and S Velocity Structure in the Coalinga Region, California, J. Geophys. Res., 95, 15.343-15.363, https://doi.org/10.1029/JB095iB10p15343, 1990.

Eberhart-Phillips, D.: Local earthquake tomography: earthquake source regions, in: Seismic Tomography: Theory and practice, edited by: Iyer, H. M. and Hirahara, K., Chapman and Hall, London, 630-642, 1993.

Evans, J. R., Eberhart-Phillips, D., and Thurber, C. H.: User's Manual for SIMULPS12 for Imaging Vp and Vp/Vs: A derivative of the "Thurber" tomographic inversion SIMUL3 for local earthquakes and Explosions. U.S. Dept. of the Interior, U.S. Geological Survey; Books and Open-File Reports Section, distributor, open File Report 94-431, 1994.

Fauzi, McCaffrey, R., Wark, D., Sunaryo, and Haryadi, P. Y. P.: Lateral variation in slab orientation beneath Toba Caldera, northern Sumatra, Geophys. Res. Lett., 23, 443-446, https://doi.org/10.1029/96GL00381, 1996.

Franke, D., Schnabel, M., Ladage, S., Tappin, D. R., Neben, S., Djajadihardja, Y. S., Mueller, C., Kopp, H., and Gaedicke, C.: The great Sumatra-Andaman earthquakes - Imaging the boundary between the ruptures of the great 2004 and 2005 earthquakes, Earth Planet. Sc. Lett., 269, 118-130, https://doi.org/10.1016/j.epsl.2008.01.047, 2008.

GEOFON Data Centre: GEOFON Seismic Network, Deutsches GeoForschungsZentrum GFZ, Other/Seismic Network, https://doi.org/10.14470/TR560404, 1993.

Graeber, F. and Asch, G.: Three-dimensional models of $P$ wave velocity and P-to-S velocity ratio in the southern central Andes by simultaneous inversion of local earthquake data, J. Geophys. Res., 104, 20.237-20.256, 1999.

Gunawan, A., Tilmann, F., Lange, D., Collings, R., Rietbrock, A., Natawidjaja, D., and Widiyantoro, S.: Moho Depth Estimation beneath Sumatera and Mentawai Islands Using Receiver Functions Recorded with a Temporary Array, EGU General Assembly 2011, Geophysical Research Abstracts, vol. 13, EGU2011-8072, 2011.

Haberland, C., Rietbrock, A., Lange, D., Bataille, K., and Dahm, T.: Structure of the seismogenic zone of the southcentral Chilean margin revealed by local earthquake traveltime tomography, J. Geophys. Res., 114, B01317, https://doi.org/10.1029/2008JB005802, 2009.

Hayes, G. P.,Wald, D. J., and Johnson, R. L.: Slab1.0: A three-dimensional model of global subduction zone geometries, J. Geophys. Res., 117, B01302, https://doi.org/10.1029/2011JB008524, 2012.

Henstock, T. J., McNeill, L. C., Bull, J. M., Cook, B. J., Gulick, S. P. S., Austin, J. A., Permana, H., and Djajadihardja, Y. S.: Downgoing plate topography stopped rupture in the A.D. 2005 Sumatra earthquake, Geology, 44, 71-74, https://doi.org/10.1130/G37258.1, 2016.

Hsu, Y.-J., Simons, M., Avouac, J.-P., Galetzka, J., Sieh, K., Chlieh, M., Natawidjaja, D., Prawirodirdjo, L., and Bock, Y.: Frictional Afterslip Following the 2005 NiasSimeulue Earthquake, Sumatra, Science, 312, 1921-1926, https://doi.org/10.1126/science.1126960, 2006.

Hyndman, R. D., Yamano, M., and Oleskevich, D. A.: The seismogenic zone of subduction thrust faults, Isl. Arc, 6, 244-260, https://doi.org/10.1111/j.1440-1738.1997.tb00175.x, 1997.

Kieckhefer, R. M., Sho, G. G., and Curray J. R.: Seismic refraction studies of the Sunda trench and forearc basin, J. Geophys. Res., 85, 863-889, 1980.

Klingelhoefer, F., Gutscher, M. A., Ladage, S., Dessa, J. X., Graindorge, D., Franke, D., Andre, C., Permana, H., Yudistira, T., and Chauhan, A.: Limits of the seismogenic zone in the epicentral 
region of the 26 December 2004 great Sumatra-Andaman earthquake: Results from seismic refraction and wide-angle reflection surveys and thermal modeling, J. Geophys. Res., 115, B01304, https://doi.org/10.1029/2009JB006569, 2010.

Kissling, E.: Geotomography with local earthquake data, Rev. Geophys., 26, 659-698, 1988.

Kissling, E., Ellsworth, W. L., Eberhart-Phillips, D., and Kradolfer, U.: Initial reference models in local earthquake tomography, J. Geophys. Res., 99, 19.635-19.646, 1994.

Kieling, K., Roessler, D., and Krueger, F. J.: Receiver function study in northern Sumatra and the Malaysian peninsula, J. Seismol., 15, 235-259, https://doi.org/10.1007/s10950-010-9222-7, 2011.

Konca, A. O., Hjorleifsdottir, V., Song, T. R. A., Avouac, J. P., Helmberger, D. V., Ji, C., Sieh, K., Briggs, R., and Meltzner, A.: Rupture Kinematics of the $2005 M_{\mathrm{W}} 8.6$ Nias-Simeulue Earthquake from the Joint Inversion of Seismic and Geodetic Data, B. Seismol. Soc. Am., 97, S307-322, 2007.

Konca, A. O., Avouac, J. P., Sladen, A., Meltzner, A. J., Sieh, K., Fang, P., Li, Z., Galetzka, J., Genrich, J., Chlieh, M., Natawidjaja, D. H., Bock, Y., Fielding, E. J., Ji, C., and Helmberger, D. V.: Partial rupture of a locked patch of the Sumatra megathrust during the 2007 earthquake sequence, Nature, 456, 631-635, 2008.

Koulakov, I., Yudistira, T., Luehr, B.-G., and Wandono: Velocity and $v_{\mathrm{p}} / v_{\mathrm{s}}$ ratio beneath the Toba caldera complex (Northern Sumatra) from local earthquake tomography, Geophys. J. Int., 177, 1121-1139, https://doi.org/10.1111/j.1365246X.2009.04114.x, 2009.

Koulakov, I., Kasatkina, E., Shapiro, N. M., Jaupart, C., Vasilevsky, A., Khrepy, S. E., Al-Arifi, N., and Smirnov, S.: The feeder system of the Toba supervolcano from the slab to the shallow reservoir, Nat. Commun., 7, 12228, https://doi.org/10.1038/ncomms12228, 2016.

Lange, D., Rietbrock, A., Haberland, C., Bataille, K., Dahm, T., Tilmann, F., and Flüh, E. R.: Seismicity and geometry of the south Chilean subduction zone $\left(41.5^{\circ} \mathrm{S}-43.5^{\circ} \mathrm{S}\right)$ : Implications for controlling parameters, Geophys. Res. Lett., 34, L06311, https://doi.org/10.1029/2006GL029190, 2007.

Lange, D., Tilmann, F., Rietbrock, A., Collings, R., Natawidjaja, D. H., Suwargadi, B. W., Barton, P., Henstock, T., and Ryberg, T.: The Fine Structure of the Subducted Investigator Fracture Zone in Western Sumatra as Seen by Local Seismicity, Earth Planet. Sc. Lett., 298, 47-56, https://doi.org/10.1016/j.eps1.2010.07.020, 2010.

Lay, T., Ammon, C. J., Kanamori, H., Yamazaki, Y., Cheung, K. F., and Hutko, A. R.: The 25 October 2010 Mentawai tsunami earthquake $\left(M_{\mathrm{W}}\right.$ 7.8) and the tsunami hazard presented by shallow megathrust ruptures, Geophys. Res. Lett, 38, L06302, https://doi.org/10.1029/2010GL046552, 2011.

Masturyono, McCaffrey, R., Wark, D. A., Roecker, S. W., Fauzi, Ibrahim, and G., Sukhyar: Distribution of magma beneath the Toba caldera complex, north Sumatra, Indonesia, constrained by three-dimensional $\mathrm{P}$ wave velocities, seismicity, and gravity data, Geochem. Geophy. Geosy., 2, https://doi.org/10.1029/2000GC000096, 2001.

Matson, R. and Moore, G. F.: Structural controls on forearc basin subsidence in the central Sumatra forearc basin. In Geology and Geophysics of Continental Margins, Am. Assoc. Petrol. Geol. Memoir, 53, 157-181, 1992.
McCaffrey, R., Zwick, P., Bock, Y., Prawirodirdjo, L., Genrich, J., Stevens, C. W., Puntodewo, S. S. O., and Subarya, C.: Strain partitioning during oblique plate convergence in northern Sumatra: Geodetic and seismologic constraints and numerical modeling, J. Geophys. Res., 105, 28363-28376, 2000.

McCloskey, J., Lange, D., Tilmann, F., Nalbant, S. S., Bell, A. F., Natawidjaja, D. H., and Rietbrock, A.: The September 2009 Padang earthquake, Nat. Geosci., 3, 70-71, https://doi.org/10.1038/ngeo753, 2010.

McNeill, L. C. and Henstock, T. J.: Forearc structure and morphology along the Sumatra-Andaman subduction zone, Tectonics, 33, 112-134, https://doi.org/10.1002/2012TC003264, 2014.

Minshull, T. A., Sinha, M. C., and Peirce, C.: Multi-disciplinary, sub-seabed geophysical imaging - A new pool of 28 seafloor instruments in use by the United Kingdom Ocean Bottom Instrument Consortium, Sea Technol., 46, 27-31, 2004.

Moore, G. F., Billman, H. G., Hehanussa, P. E., and Karig, D. E.: Sedimentology and paleo- bathymetry of Neogene trenchslope deposits, Nias Island, Indonesia, J. Geol., 88, 161-180, https://doi.org/10.1086/628489, 1980.

Moore, G. F., Curray, J. R., and Emmel, F. J.: Sedimentation in the Sunda Trench and forearc region, Geol. Soc. London Spec. Publ., 10, 245-258, 1982.

Muksin, U., Bauer, K., and Haberland, C.: Seismic $v_{\mathrm{p}}$ and $v_{\mathrm{p}} / v_{\mathrm{s}}$ structure of the geothermal area around Tarutung (North Sumatra, Indonesia) derived from local earthquake tomography, J. Volcanol. Geoth. Res., 260, 27-42, https://doi.org/10.1016/j.jvolgeores.2013.04.012, 2013.

Mukti, M. M., Singh, S. C., Deighton, I., Hananto, N. D., Moeremans, R., and Permana, H.: Structural evolution of backthrusting in the Mentawai Fault Zone, offshore Sumatran forearc, Geochem. Geophy. Geosy., 13, https://doi.org/10.1029/2012GC004199, 2012.

Natawidjaja, D. H., Sieh, K., Chlieh, M., Galetzka, J., Suwargadi, B. W., Cheng, H., Edwards, R. L., Avouac, J.-P,. and Ward, S. N.: Source parameters of the great Sumatran megathrust earthquakes of 1797 and 1833 inferred from coral microatolls, J. Geophys. Res, 111, B06403, https://doi.org/10.1029/2005JB004025, 2006.

Newcomb, K. R. and McCann, W. R.: Seismic history and seismotectonics of the Sunda arc, J. Geophys. Res, 92, 421-439, 1986.

Newman, A. V., Hayes, G., Wei, Y., and Convers, J.: The 25 October 2010 Mentawai tsunami earthquake, from real-time discriminants, finite-fault rupture, and tsunami excitation, Geophys. Res. Lett., 38, https://doi.org/10.1029/2010GL046498, 2011.

Oleskevich, D. A., Hyndman, R. D., and Wang, K.: The updip and downdip limits to great subduction earthquakes: Thermal and structural models of Cascadia, south Alaska, SW Japan, and Chile, J. Geophys. Res., 104, 14.965-14.991, 1999.

Pesicek, J. D., Thurber, C. H., Zhang, H., DeShon, H. R., Engdahl, E. R., and Widiyantoro, S.: Teleseismic double-difference relocation of earthquakes along the Sumatra-Andaman subduction zone using a 3-D model, J. Geophys. Res., 115, B10303, https://doi.org/10.1029/2010JB007443, 2010.

Rivera, L., Sieh, K., Helmberger, D., and Natawidjaja, D.: A comparative study of the sumatran Subduction-Zone earthquakes of 1935 and 1984, B. Seismol. Soc. Am, 92, 1721-1736, https://doi.org/10.1785/0120010106, 2002.

Ryberg, T. and Haberland, C.: Lake Toba seismic network, Sumatra, Indonesia. Deutsches GeoForschungsZentrum GFZ, 
Other/Seismic Network, https://doi.org/10.14470/2N934755, 2008.

Sakaguchi, K., Gilbert, H., and Zandt, G.: Converted wave imaging of the Toba Caldera, Indonesia, Geophys. Res. Lett., 33, L20305, https://doi.org/10.1029/2006GL027397, 2006.

Shulgin, A., Kopp, H., Klaeschen, D., Papenberg, C., Tilmann, F., Flueh, E. R., Franke, D., Barckhausen, U., Krabbenhoeft, A., and Djajadihardja,Y.: Subduction system variability across the segment boundary of the 2004/2005 Sumatra megathrust earthquakes, Earth Planet. Sc. Lett., 365, 108-119, https://doi.org/10.1016/j.epsl.2012.12.032, 2013.

Singh, S. C., Hananto, N. D., Chauhan, A. P. S., Permana, H., Denolle, M., Hendriyana, A., and Natawidjaja, D.: Evidence of active backthrusting at the NE Margin of Mentawai Islands, SW Sumatra, Geophys. J. Int., 180, 703-714, https://doi.org/10.1111/j.1365-246X.2009.04458.x, 2010.

Singh, S. C., Hananto, N., Mukti, M., Robinson, D.P., Das, S., Chauhan, A., Carton, H., Gratacos, B., Midnet, S., Djajadihardja, Y., and Harjono, H.: Aseismic zone and earthquake segmentation associated with a deep subducted seamount in Sumatra, Nat. Geosci., 4, 308-311, https://doi.org/10.1038/ngeo1119, 2011.

Sieh, K. and Natawidjaja, D.: Neotectonics of the Sumatran fault, Indonesia, J. Geophys. Res., 105, 28295-28326, 2000.

Sieh, K., Natawidjaja, D. H., Meltzner, A. J., Shen, C., Cheng, H., Li, K., Suwargadi, B. W., Galetzka, J., Philibosian, B., and Edwards, R. L.: Earthquake Supercycles Inferred from Sea-Level Changes Recorded in the Corals of West Sumatra, Science, 322, 1674-1678, https://doi.org/10.1126/science.1163589, 2008.

Stankiewicz, J., Ryberg, T., Haberland, C., Fauzi, and Natawidjaja, D.: Lake toba volcano magma chamber imaged by ambient seismic noise tomography, Geophys. Res. Lett., 37, L17306, https://doi.org/10.1029/2010GL044211, 2010.

Simoes, M., Avouac, J. P., Cattin, R., and Henry, P.: The Sumatra subduction zone: A case for a locked fault zone extending into the mantle, J. Geophys. Res., 109, B10402, https://doi.org/10.1029/2003JB002958, 2004.

Tang, G., Barton, P. J., McNeill, L. C., Henstock, T. J., Tilmann, F., Dean, S. M., Jusuf, M. D., Djajadihardja, Y. S., Permana, H., Klingelhoefer, F., and Kopp, H.: 3-D active source tomography around Simeulue Island offshore Sumatra: Thick crustal zone responsible for earthquake segment boundary, Geophys. Res. Lett., 40, 48-53, https://doi.org/10.1029/2012GL054148, 2013.
Tilmann, F. J., Craig, T. J., Grevemeyer, I., Suwargadi, B., Kopp, H., and Flueh, E.: The updip seismic/aseismic transition of the Sumatra megathrust illuminated by aftershocks of the 2004 Aceh-Andaman and 2005 Nias events, Geophys. J. Int., 181, 1261-1274, https://doi.org/10.1111/j.1365-246X.2010.04597.x, 2010.

Thurber, C. and Eberhart-Phillips, D.: Local earthquake tomography with flexible gridding, Comput. Geosci., 25, 809-818, https://doi.org/10.1016/S0098-3004(99)00007-2, 1999.

Thurber, C. H.: Earthquake locations and three-dimensional crustal structure in the Coyote Lake area, Central California, J. Geophys. Res., 88, 8.226-8.236, https://doi.org/10.1029/JB088iB10p08226, 1983.

Tichelaar, B. W. and Ruff, L. J.: Depth of seismic coupling along subduction zones, J. Geophys. Res., 98, 2.017-2.037, 1993.

Toomey, D. R. and Foulger, G. R.: Tomographic inversion of local earthquake data from the Hengill-Grensdalur central volcano complex, Iceland, J. Geophys. Res., 94, 17.497-17.510.2, 1989.

Um, J. and Thurber, C. H.: A fast algorithm for two-point ray tracing, B. Seismol. Soc., Am, 77, 972-986, 1987.

Vermeesch, P. M., Henstock, T. J., Lange, D., McNeill, L. C., Barton, P. J., Tang, G., Bull, J. M., Tilmann, F., Dean, S. M., Djajadihardja, Y., and Permana, H.: 3-D tomographic seismic imaging of the southern rupture barrier of the great Sumatra-Andaman 2005 earthquake, Geophysical Research Abstracts, Vol. 11, EGU2009. 11509, EGU General Assembly Vienna, 2009.

Weller, O., Lange, D., Tilmann, F., Natawidjaja, D., Rietbrock, A., Collings, R., and Gregory, L.: The structure of the Sumatran Fault revealed by local seismicity, Geophys. Res. Lett., 39, L01306, https://doi.org/10.1029/2011GL050440, 2012.

Wiseman, K., Banerjee, P., Sieh, K., Bürgmann, R., and Natawidjaja, D. H.: Another potential source of destructive earthquakes and tsunami offshore of Sumatra, Geophys. Res. Lett. 38, L10311, https://doi.org/10.1029/2011GL047226, 2011.

Wiseman, K., Banerjee, P., Bürgmann, R., Sieh, K., Dreger, D. S., and Hermawan, I.: Source model of the $2009 M_{\mathrm{w}} 7.6$ Padang intraslab earthquake and its effect on the Sunda megathrust, Geophys. J. Int., 190, 1710-1722, https://doi.org/10.1111/j.1365246X.2012.05600.x, 2012. 